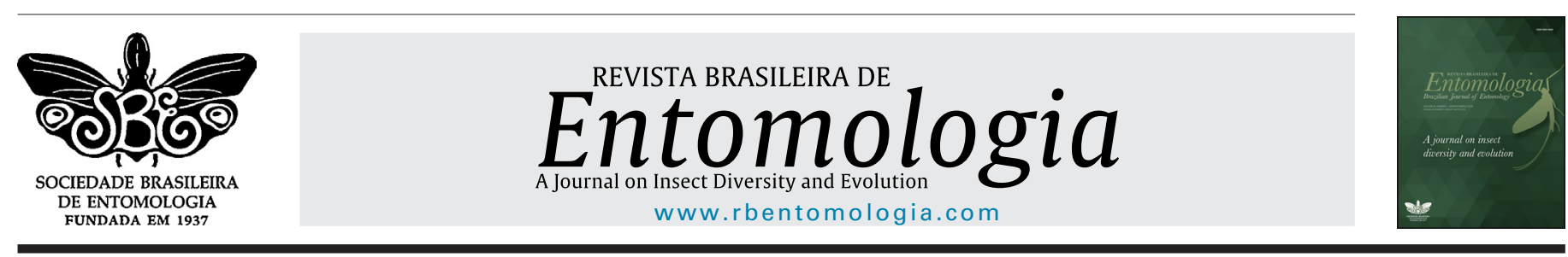

\title{
Revision of the rare anthidiine bee genus Rhynostelis Moure \& Urban (Hymenoptera, Apidae)
}

\author{
Daniele R. Parizotto ${ }^{*}$ (D), Gabriel A.R. Melo² (D) \\ ${ }^{1}$ Universidade Federal Rural de Pernambuco, Departamento de Agronomia, Recife, PE, Brazil \\ ${ }^{2}$ Universidade Federal do Paraná, Departamento de Zoologia, Laboratório de Biologia Comparada de Hymenoptera, Curitiba, PR, \\ Brazil \\ urn:lsid:zoobank.org:pub:3D06396B-D9E4-48B7-A43E-C845D4C0A145
}

\section{A R T I C L E I N F O}

\section{Article history:}

Received 26 December 2019

Accepted 24 March 2020

Available online 01 June 2020

Associate Editor: Rodrigo Gonçalves

\section{Keywords:}

Anthidiini

Megachilidae

Neotropical region

New species

\begin{abstract}
A B S T R A C T
The bee genus Rhynostelis Moure \& Urban, a cleptoparasite taxon restricted to the Neotropical Region, was previously known from a single species. In the present work, the genus is revised, with three species recognized, of which two are described as new: Rhynostelis chrysogaster sp. nov. and Rhynostelis plesiognatha sp. nov. from Panamá and Brazil, respectively. Misidentification of the type species, Rhynostelis multiplicata (Smith, 1879), in previous works is pointed out and discussed. Diagnosis, illustrations and an identification key for the three recognized species are also provided.
\end{abstract}

\section{Introduction}

Anthidiini is one the most diverse taxa of megachiline bees in the Neotropical region with approximately 350 described species (Urban and Moure, 2007). Among these Neotropical representatives, seven genera are known to behave as obligatory cleptoparasites, attacking not only other anthidiine bees but also nests of unrelated bee groups (summary in Parizotto and Urban, 2012). Two cleptoparasitic genera, Rhynostelis Moure and Urban and Melostelis Urban, are known to contain a single species each. These are very rarely collected bees and are currently known from six specimens, Melostelis only from the female holotype and Rhynostelis from four females, including the holotype, and a single male (Urban and Moure, 2007; Urban, 2011; Parizotto and Urban, 2012).

Rhynostelis contains large and robust bees (13-16 mm of body length) with strong yellow markings on all tagmata, previously known from Amazonas, Brazil and French Guiana. Rhynostelis together with Hoplostelis are known to parasitize euglossine orchid bees: the latter parasitizes nests of Euglossa (Bennett, 1966; Augusto and Garófalo, 1998; Urban, 2003), while the former has been recorded from nests

\footnotetext{
* Corresponding author:

E-mail: dparizotto@gmail.com (D.R. Parizotto).
}

of Eufriesea (Moure and Urban, 1995; Parizotto and Urban, 2012). The females of Rhynostelis and Hoplostelis possess a mandibular projection that is probably used to open the resinous brood cells of their hosts, and not to kill the host eggs or larvae as suggested by Michener (2007). For Hoplostelis, Augusto and Garófalo (1998) have provided details of how the females behave while inside the nests of their Euglossa hosts. In the case of Rhynostelis, very little is known about the biology besides their bee hosts.

Discovery of two females of Rhynostelis in the collection of the Hungarian Natural History Museum, both of which did not match the then current concept for the type species, has called for a revision of the genus. This has led us to reexamine the type material of Anthidium multiplicatum Smith, 1879, the type species of Rhynostelis, and to find out that the interpretation made by Moure and Urban (1995) was incorrect. This interpretation was followed by Parizotto and Urban (2012), who had mistaken the specimens they studied from Manaus and Belém, in Brazil, as belonging to $R$. multiplicata, instead of an undescribed new species. Here we recognize three species in Rhynostelis, two of them as new. We also provide an updated diagnosis for the genus, key to species identification and photographs of all species including the type of Anthidium multiplicatum. 


\section{Material and methods}

The studied material was obtained from the following institutions: DZUP, Coleção de Entomologia Pe. Jesus Santiago Moure, Universidade Federal do Paraná, Curitiba, Brazil; HNHM, Hungarian Natural History Museum, Budapest, Hungary. The additional acronyms cited in the text refer to the following collections: INPA, Coleção de Invertebrados do Instituto Nacional de Pesquisas da Amazônia, Manaus, Amazonas, Brazil; NHMUK, Natural History Museum, London, England.

The labels of the type specimens were transcribed in the Type material section, examined in the following way: one inverted bar $(\backslash)$ to indicate different lines on the label and quotation marks to indicate different labels on the same specimen. The terminology follows Urban (1967) and Michener (2007), except for the mandible that follows
Michener and Fraser (1978). The abbreviations T and S are used for metasomal terga and sterna, respectively. The color images of the new species were taken with a LEICA DFC295 digital camera attached to the stereoscopic microscope LEICA M125, and finished in the software Zerene Stacker (1.04 version build).

\section{Taxonomy}

\section{Rhynostelis Moure and Urban, 1995}

(Figs. 1-21)

Type species: Anthidium multiplicatum Smith, 1879 by original designation.

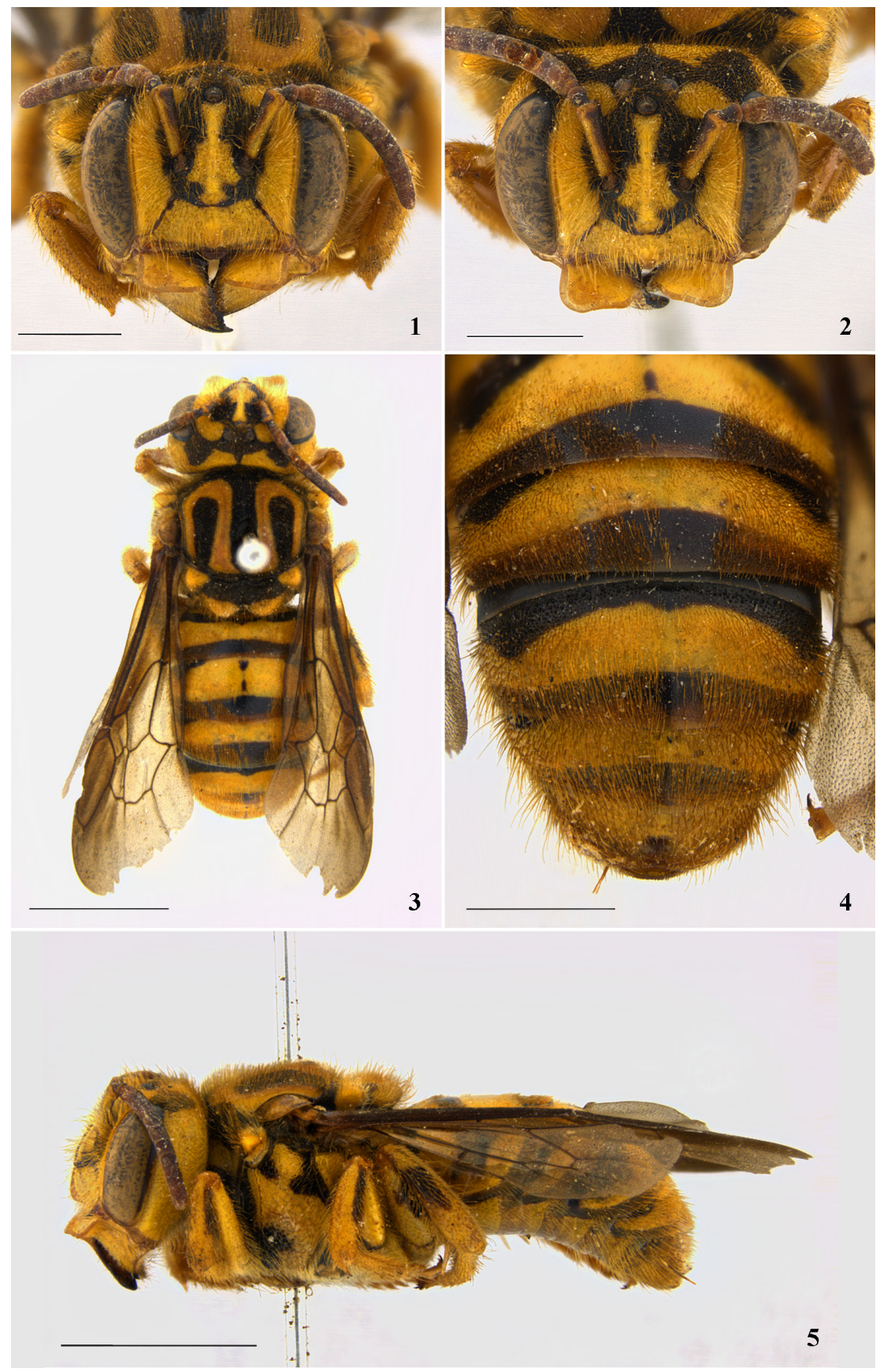

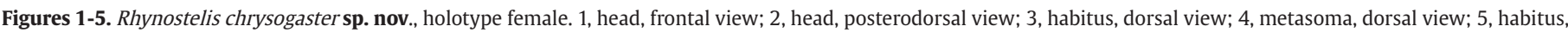
lateral view. Scale line $=2.0 \mathrm{~mm}$ (Figs. 1, 2 and 4). Scale line $=5.0 \mathrm{~mm}$ (Figs. 3, 5). 
Rhynostelis was described as a monotypic cleptoparasitic genus based on only two females originating from the Amazonas state, in northern Brazil: a female collected by Henry Bates in São Paulo de Olivença and described as male by Smith (1879) under the name Anthidium multiplicatum, and a second female that emerged from a nest of Eufriesea built within the walls of a termite nest in Manaus (Moure and Urban, 1995). Moure and Urban (1995) assumed that the female from Manaus belonged to the same species based on the manuscript note made by Moure of the type specimen of $R$. multiplicata and most likely on Moure's own recollection of the specimen. After examining photographs of the type specimen deposited in the NHMUK (Figs. 16-21), we concluded that the two females interpreted as Rhynostelis multiplicata by Moure and Urban (1995) actually correspond to two distinct species. Additionally, we recognize here a third new species of the genus from Panamá. The three species have similar color pattern and can be easily distinguished mainly by details of structure of the female mandible, clypeus and supraclypeal area.
The species of Rhynostelis can be recognized by the combination of a carinate frons; juxtantennal carina present; strong paraocular carina; pronotal lobe with short lamina; omaulus lamellate, almost extending ventrally; bigibbous scutum and scutellum; scutoscutellar suture broad and forming two foveae; fore and mid tibiae with one midapical spine on outer surface; hind tibia with flat apical projection on outer surface (more developed in females); arolia present; base of propodeum with irregular foveae. In addition, the females exhibit a tubercle or projection on the supraclypeal area; mandibles with raised condylar carina and a strong antero-basal projection.

Key to females of Rhynostelis (only the male of $R$. plesiognatha sp. nov. is known)

1. Mandible with bifurcated condylar carina; axillae rounded; scutellum with shallow posterior emargination (Fig. 8); tergal pilosity brown to black (Figs. 9 and 14); disc of T2 with larger and deeper punctures on its basal third
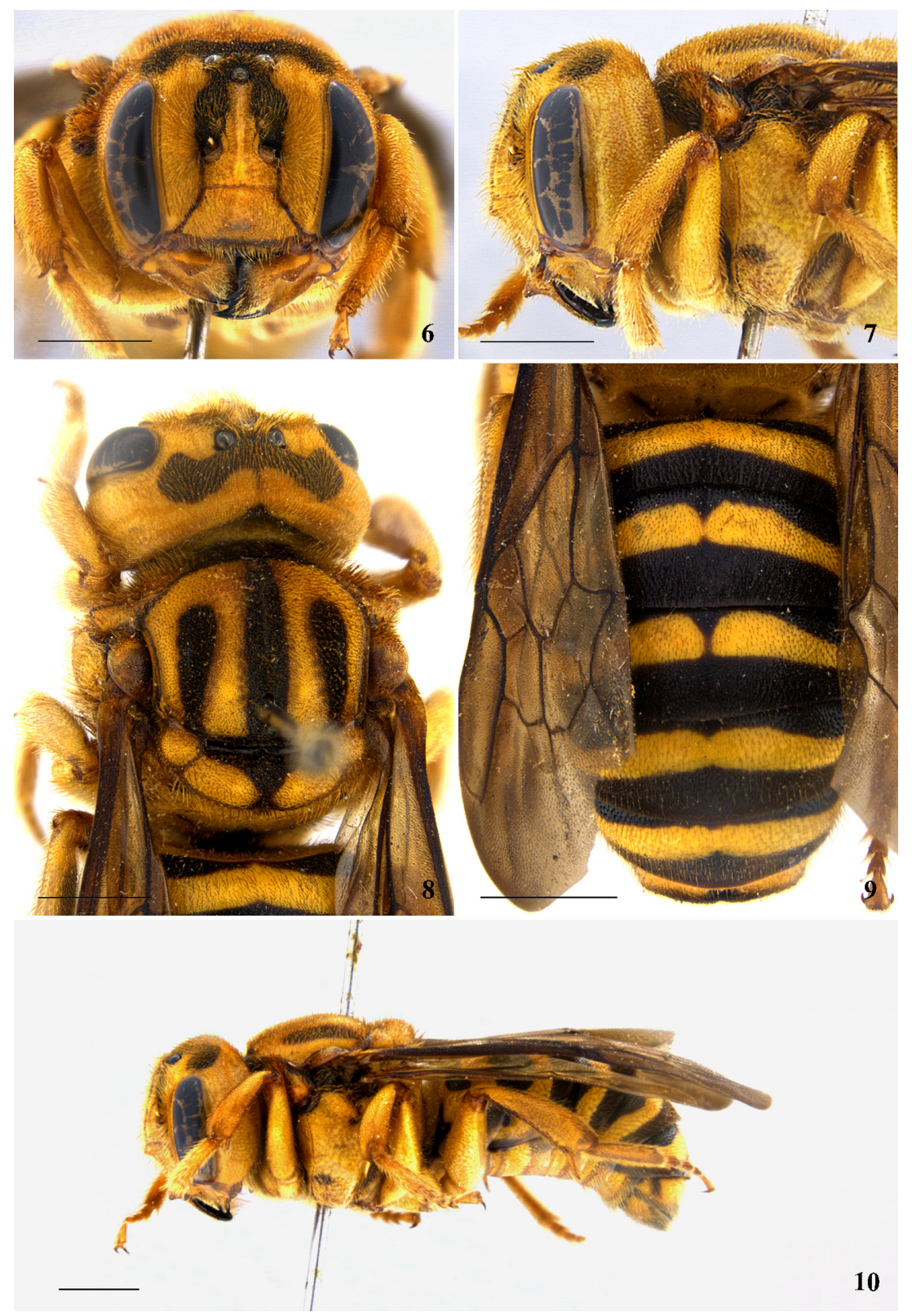

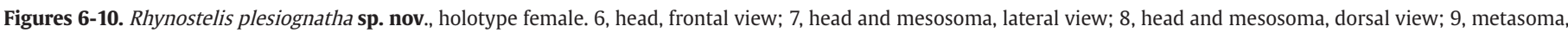
dorsal view; 10, habitus, lateral view. Scale line $=2.0 \mathrm{~mm}$. 

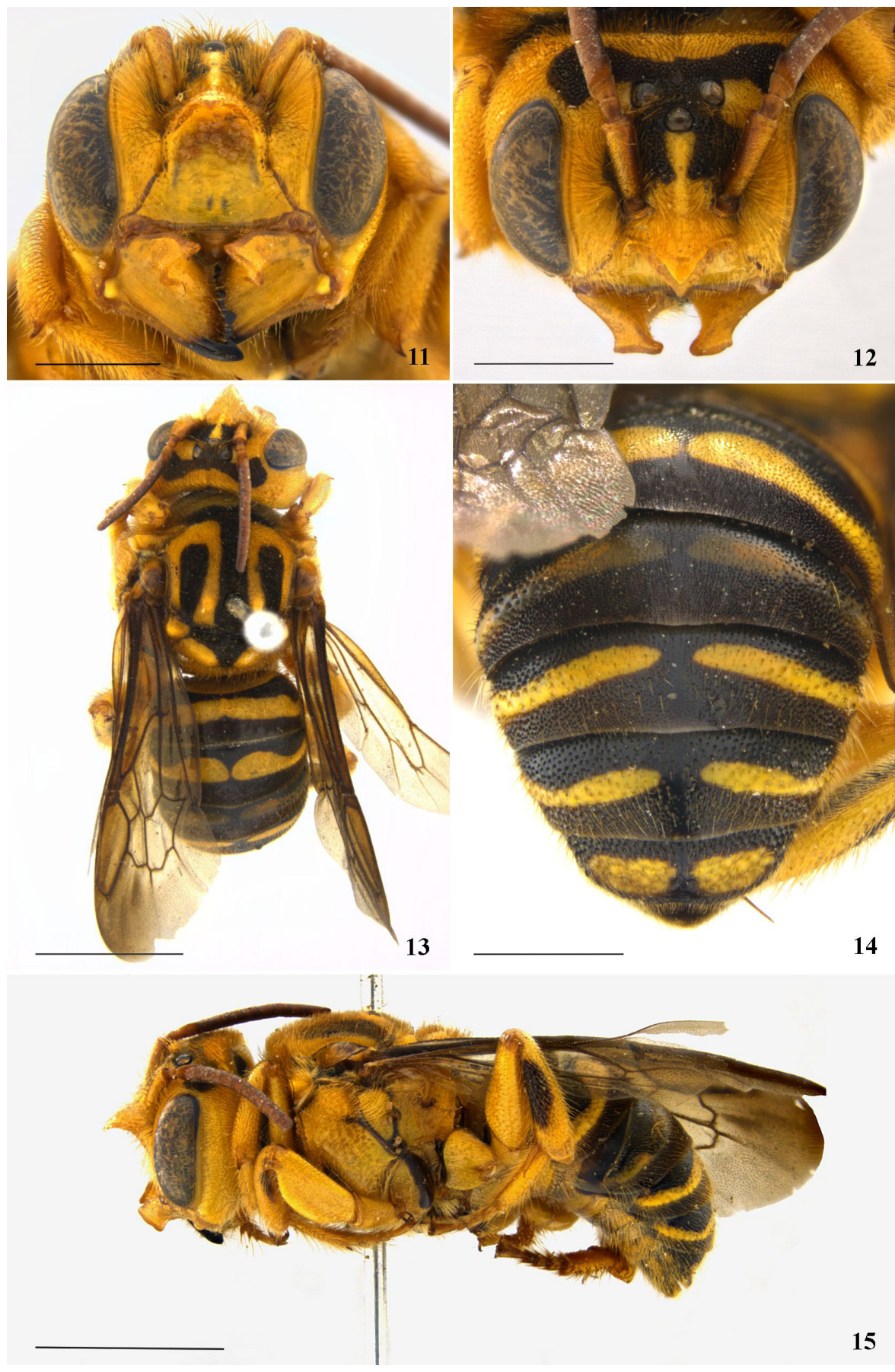

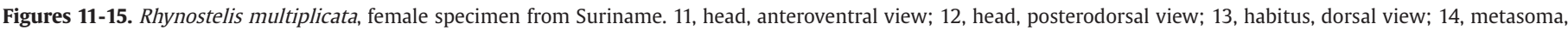
dorsal view; 15, habitus, lateral view. Scale line $=2.0 \mathrm{~mm}$ (Figs. 11, 12 and 14). Scale line = $5.0 \mathrm{~mm}$ (Figs. 13 and 15).

1'. Mandible with simple condylar carina; axillae somewhat triangular; scutellum with strong posterior emargination (Fig. 3); tergal pilosity yellowish ferruginous (Fig. 4); disc of T2 with shallow punctures throughout

Rhynostelis chrysogaster sp. nov.

2. Supraclypeal area not raised, except for the medial carina; clypeus with a small medial tubercle on its upper margin; mandible with a short truncate projection near anterior articulation (Figs. 6 and 7) .....

Rhynostelis plesiognatha sp. nov.

2'. Supraclypeal area and upper margin of clypeus with a large beak-shaped protuberance; mandible with a large horn-shaped projection near anterior articulation (Figs. 11 and 12)..

Rhynostelis multiplicata

\section{Rhynostelis chrysogaster sp. nov.}

(Figs. 1-5)

Diagnosis. Clypeus and supraclypeal area protuberant, ending in a short medial tubercle on upper margin of clypeus; base of the mandible with broad and strongly-raised laminar projection (Figs. 1 and 2); axillae projecting posteriorly, somewhat triangular; scutellum distinctly projected posteriorly and forming a strong medial emargination (Fig. 3); tergal pilosity yellowish ferruginous (Fig. 4).

Description. Holotype female. Approximate body length $13.3 \mathrm{~mm}$; forewing length $10.8 \mathrm{~mm}$; head width $4.6 \mathrm{~mm}$; eye length $2.7 \mathrm{~mm}$. 
Color. Head integument yellow except: distal margin of mandible and apical tooth blackish; irregular black band above clypeus extending upwards, including ocelli, and connecting with black spot on vertex above compound eyes. Antenna light brown with dorsal surface of scape yellow; apex of pedicel and first flagellomere ferruginous (Figs. 1 and 2). Pronotal lobe with a large yellow macula; scutum black with large reverse U-shaped yellow maculae; scutellum with two yellow bands on apex; axilla yellow; metanotum black; propodeum yellow except for the black propodeal spiracle (Fig. 3). Mesepisternum mostly yellow, only with three irregular black maculae. Metepisternum largely yellow on its dorsal half and black ventrally. Tegula amber and fore wing membrane brown infumated, especially along costal margin (Fig. 3). Legs almost totally yellow; fore coxae with half basal brown; fore and mid tibiae with darkish area on inner surface; hind legs with irregular darkish maculae on inner surface of femur and outer surface of tibia. Terga black with yellow maculae; yellow band on T1 broad, slightly narrower at middle; T2-T5 with even broader yellow band, T2 with two small brown spots medially; T4-T5 with larger translucent ferruginous margin; distal tergum yellow with a median subapical blackish spot (Figs. 3 and 4). Sterna yellow, with large translucent margin on S1-S5. Pubescence. Yellowish with long hairs (longer than ocellus diameter). Pilosity longer and denser between ocelli, above antennal sockets and on clypeus (Fig. 2). Hairs on mesepisternum and legs longer than those on mesoscutum, slightly curved on pronotal lobe and apex of scutellum. Fore and mid legs with coxae and trochanter covered by denser pilosity. Terga covered by dense yellowish ferruginous pilosity (Fig. 4). S1-S5 with sparse light yellow hairs along posterior margin; S6 with light yellow hairs covering entire tergum. Sculpturing. Head with shallow punctures, sparser on clypeal protuberance and supraclypeal area. Mesosoma with integument microreticulated, mesoscutum with punctures deep and confluent, separated only by their crests, slightly sparser on yellow areas; mesespisternum with larger and sparser punctures, distance between punctures at least one-half of puncture diameter. Scutellum with punctures sparser than those on mesoscutum; with large punctures intercalated with small punctures, separated by least a puncture diameter. Terga microreticulated; punctures on disc of T1-T5 fine and shallow; punctures on yellow bands larger and sparser than those on black areas; distal tergum with deeper and larger punctures. Structure. Mandible with condylar carina simple; antero-basal protuberance, near anterior articulation, broad and strongly raised, spatulate. Supraclypeal area with protuberant medial carina continuing onto clypeus, ending as a short medial protuberance on upper margin of clypeus (Figs. 1, 2 and 5). Axilla somewhat triangular and separated from scutellum by deep emargination; scutellum with strong medial emargination along posterior margin (Fig. 3).

Male unknown.

Type material. Holotype female (HNHM), "Amer. cent.| Chiriqui” "Hungarian Natural \History Museum\ Hymenoptera Coll \Budapest". The holotype is in perfect condition, except for the partially damaged flagellomeres 3-5 of right antenna.

Distribution. Currently known only from Chiriqui, Panamá.

Etymology. The species epithet refers to the golden pilosity of its metasoma, from the Greek chrysos, gold, and gaster, abdomen.

\section{Rhynostelis plesiognatha sp. nov.}

(Figs. 6-10)

Stelis (Hoplostelis) tuberculata, nomen nudum. Dominique, 1898: 61.

Comments. The female from Manaus, Brazil, previously identified as R. multiplicata in Moure and Urban (1995), and a pair of specimens from Belém, Pará, Brazil, identified as $R$. multiplicata by Parizotto and Urban (2012), correspond to a distinct species newly described here. The female specimen from French Guiana (examined by photos) mentioned in Dominique (1898) under the nomen nudum "Stelis tuberculata" and placed by Rasmussen et al. (2007) and Urban and Moure (2007) under $R$. multiplicata also belongs to this new species. The male was described and illustrated by Parizotto and Urban (2012) as $R$. multiplicata.

Diagnosis. This new species is more similar to R. multiplicata by the color pattern; the axillae rounded; scutellum with shallow posterior emargination (Fig. 8) and tergal pilosity brown to black (Figs. 9 and 14). The females of $R$. plesiognatha sp. nov. can be easily distinguished by their less modified clypeus, provided only with a short tubercle on the upper margin and lacking the strongly raised beak-like projection of $R$. multiplicata, and by its simpler mandible, with a short truncate projection near the anterior articulation (Figs. 6 and 7).

Description. Holotype female. Approximate body length $16 \mathrm{~mm}$; forewing length $12.2 \mathrm{~mm}$; head width $5.3 \mathrm{~mm}$; eye length $3.1 \mathrm{~mm}$. Color. Head integument yellow except: distal margin of mandible and apical tooth blackish; black band on supraclyeal area extending upward to vertex (Figs. 6 and 7). Pronotal lobe yellow; scutum black with reverse U-shaped yellow maculae almost reaching the scutoscutellar suture; scutellum with two large subapical yellow bands; axilla yellow. Mesepisternum yellow, with a little black spot medially. Tegula reddish brown, with a yellow spot anteriorly; fore wing membrane brown infumated throughout. Legs predominantly yellow (Figs. 8 and 10). Terga black with yellow maculae; yellow band on T1 angled at middle; yellow band on T2-T5 wider and slightly interrupted medially; T6 with two large yellow spots (Fig. 9). Three basal sterna yellow, with large translucent margin; S4 yellow with dark infuscated area medially; S6 black with two lateral yellow spots. Pubescence. Head and mesosoma with mostly light yellowish ferruginous pilosity, shorter than ocellar diameter. Pubescence longer and denser between ocelli, above antennal sockets and lower margin of clypeus. Hairs of mesepisternum slightly longer and denser than those on mesoscutum (Fig. 8). Pilosity of terga as in $R$. multiplicata. Sculpturing. Head with shallow and coalescent punctures; smaller and fine on disc of clypeus. Mesoscutum with deeper and smaller punctures than those on head. Gibbous area of mesepisternum with punctures sparser than on mesoscutum. Punctures of terga fine and shallow; punctures on yellow bands larger and sparser than those on black areas (Fig. 9); distal tergum with larger punctures. Structure. Mandible with bifurcated condylar carina, antero-basal projection short and truncate; supraclypeal area not raised, except for the medial carina; clypeus with a small medial tubercle on its upper margin (Figs. 6 and 7).

Paratype male. Approximate body length 13.3; forewing length 10.5; head width 4.0; head length 3.77; eye length 2.5. Color. Integumental marks as in the female except for: T2-T5 with yellow band wider medially and slightly interrupted on T2-T3; T5 with yellow band emarginated at middle on posterior margin; T6 with broad yellow band, wider medially; T7 with subapical yellow band with blackish margin. Two basal sterna yellow, with large translucent margin; S3-S5 yellow with dark infuscated area on apical half; $\mathrm{S} 6$ with a median black spot. Pubescence and Sculpturing. As in female except for a more conspicuous pilosity in paraocular area and coxae. Structure. Mandibles with only apical tooth; condylar carina distinctly raised, almost laminated; T7 short and sinuous at middle; S6 with large lateral laminar projections.

Type material. Holotype female (DZUP): Pará, Belém, "IPEAN [Instituto de Pesquisas e Experimentação Agropecuária do Norte, Belém] \105-1 \EU". The holotype is in perfect condition, except for the broken antennae, which have been glued to one of the specimen labels. Paratypes: one male (DZUP), Pará, Belém "IPEAN [Instituto de Pesquisas e Experimentação Agropecuária do Norte, Belém] \105-2 \ 
EU”; one female (DZUP), Amazonas, Manaus, “Proj. [Project] DBFF.WWF| Manaus-AM $\backslash$ Brasil 04/11/89 / M. B. V. Garcia".

Distribution. This species is known from Brazil (Amazonas and Pará) and French Guiana.

Etymology. The species is named in reference to its less complex mandible, in comparison to the other species, from the Greek plesios, near, and gnathos, mandible.

\section{Rhynostelis multiplicata (Smith, 1879)}

(Figs. 11-21)

Anthidium multiplicatum Smith, 1879: 87. Holotype female, Brazil: Amazonas, São Paulo de Olivença (NHMUK, examined through photographs).

Rhynostelis xavieri Mahlmann, 2020: 2. Holotype female, Brazil: Amazonas, Benjamin Constant (INPA, not examined). New synonym

Comments. The identity of the type species of Rhynostelis is interpreted here based on the type specimen (Figs. 16-21). Smith (1879) described this species from a single specimen collected by Henry Bates in São Paulo de Olivença, Amazonas, in northern Brazil. He assumed that it was a male, probably because of lack of a metasomal scopa.

Moure and Urban (1995) proposed their genus Rhynostelis based on Smith's species and corrected the information on the sex of the type specimen. Moure had studied the specimen in his visit to the Natural History Museum, London, in 1957. His notes are quite detailed and in reality were made in the form of a description of a new genus (named under a slightly different spelling; see photography of his label in Fig. 21). The formal proposal of the new genus, however, was published only many years later and was based on a female specimen collected in Manaus (see above), instead of Moure's own original manuscript description. Had Moure and Urban used the manuscript description, they could have realized that the specimen from Manaus was not conspecific with the type specimen. For this reason, we present here a diagnosis and a redescription for Rhynostelis multiplicata based on the photos of the holotype of Anthidium multiplicatum, on Moure's notes and on study of an additional female from Suriname (Figs. 11-15).

Diagnosis. Rhynostelis multiplicata is most similar to $R$. plesiognatha sp. nov., both exhibiting a bifurcated condylar carina, but differs by a beak-shaped protuberance on supracypeal area and a large horn-shaped projection on the base of mandible (Figs 11-13, 15-18).

Redescription of female.

Color. Head predominantly yellow except for following black areas: distal margin of mandible; labrum; band above antennal sockets extending upwards, including ocelli and merging with the black maculae of the vertex (Figs. 11, 12, 16 and 17). Antenna ferruginous with dorsal surface of scape yellowish tinged. Pronotal lobe light yellow; scutum black with reverse
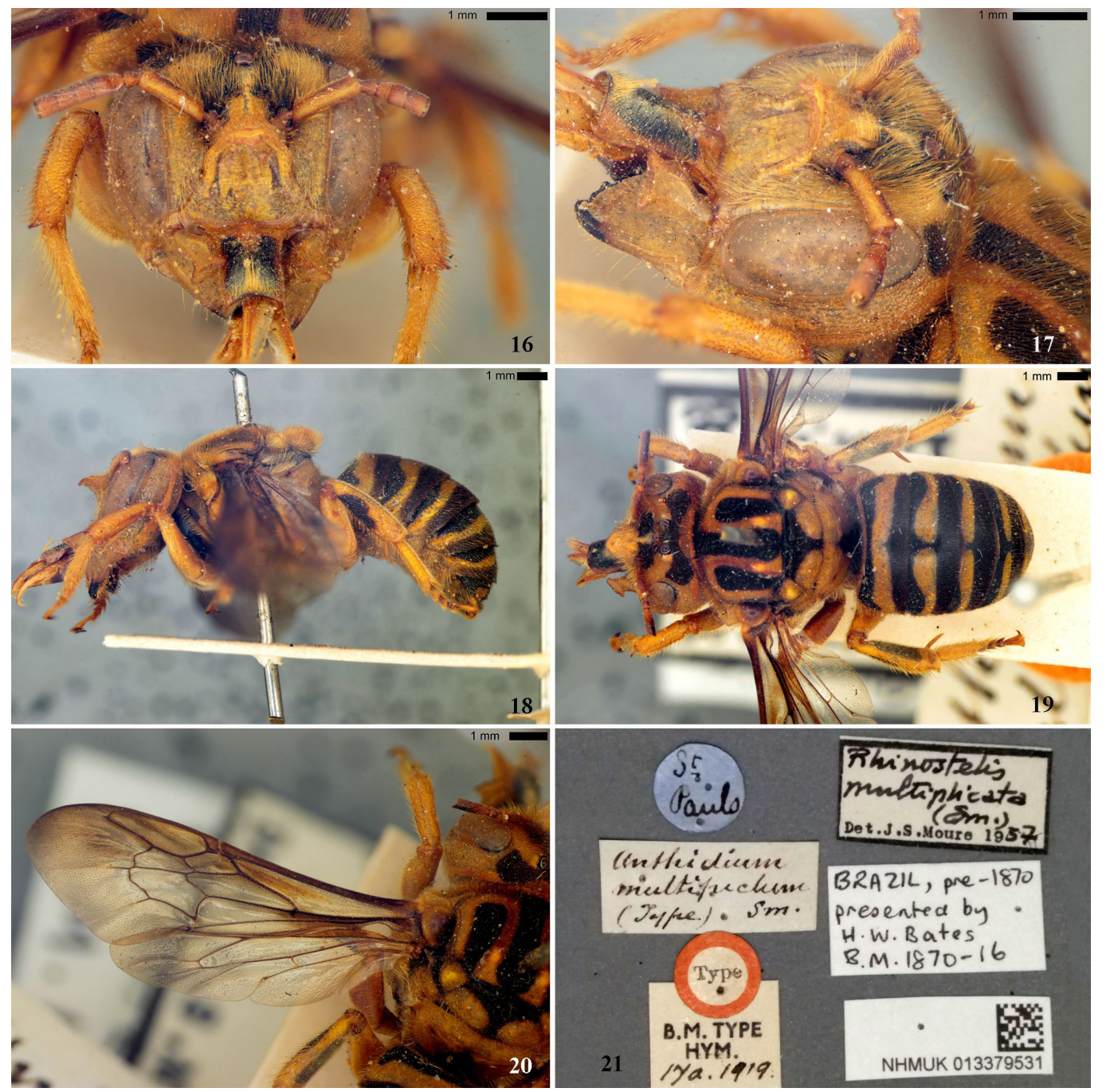

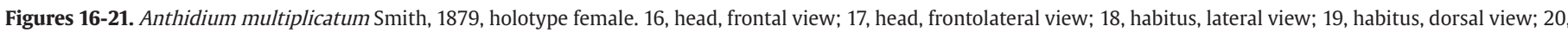
detail of left wings; 21 . Specimen labels. 
U-shaped yellow maculae; scutellum with two large yellow spots, axillae yellow; metanotum black; propodeum yellow except by a medial black band. Mesepisternum yellow. Tegula amber with the margin yellowish tinged; wing membrane mostly infumated brown, darker at base and along costal margin (Fig. 13). Legs predominantly yellow; mid leg with a black spot on coxae and a small spot on ventral area of tibiae; hind tibia with darkish macula on inner surface (Fig. 15). Terga black with yellow maculae; yellow band on T1 continuous; yellow bands on T2-T3 wider medially, in particular on $\mathrm{T} 2$, and with a narrow medial interruption; yellow band on T4-T5 narrower and with a wider interruption medially; T6 with two median yellow spots (Figs. 14 and 19). Pubescence. As in R. chrysogaster sp. nov. except for brown hairs on terga (Fig. 14). Sculpturing. Head with shallow punctures, sparser on supraclypeal area; disc of clypeus smooth. Mesoscutum, scutullem and axillae with smaller and deeper punctures, sparser on gibbous areas. Mesepisternum and metepisternum with larger, shallower and sparser punctures than mesoscutum. T1-T5 with dense punctures, anterior half with larger and deeper punctures and posterior half finely punctate; punctures on T4 and T5 sparser and deeper than those on T3; T6 with deeper and denser punctures than T5. Structure. Mandible with bifurcated condylar carina elevated and with a large hornshaped projection near anterior articulation; supraclypeal area and upper margin of clypeus with a large beak-shaped protuberance (Figs. 11 and 12). Scutellum with a shallow medial emargination posteriorly (Figs. 13 and 19).

Male unknown.

Type material. The holotype of Anthidium multiplicatum, examined through photographs (NHMUK), bears the labels (Figs. 16-21): "St.|Paulo" "Anthidium|multiplicatum|(Type) Sm." “Type” "B.M.TYPE|HYM.|17a.1919" "Rhinostelis $\backslash$ multiplicata|(Sm.)| Det.J.S.Moure 1957" "BRAZIL, pre-1870| presented by|H.W.Bates|B.M. 1870-16" “NHMUK 013379531".

Additional material examined. One female (HNHM), "Amer. mer.|Surinam" "Hungarian Natural |History Museum| Hymenoptera Coll $\backslash$ Budapest".

Distribution. The only three known records are from São Paulo de Olivença and Benjamin Constant, southwestern Amazonas, in Brazil, and from Suriname, in northern South America.

\section{Supplemental note}

While this article was on production, a paper dealing with the genus Rhynostelis was published by Mahlmann (2020), in which the author proposes a new species, Rhynostelis xavieri, based on a single female collected in Benjamin Constant, Amazonas, Brazil. Although the holotype of the new species has not been directly examined, it is illustrated in the original paper by four photographs with good quality, showing different angles of the specimen. The illustrations and the diagnostic characters presented by Mahlmann (2020) leave no doubt that Rhynostelis xavieri is a synonym of Rhynostelis multiplicata. Also, the type localities of the two taxa are relatively close to each other in the western portion of the Amazonas state, being only about $150 \mathrm{~km}$ apart in a straight line. The present situation exemplifies the pitfalls of proposing new taxa outside the context of revisionary work and without examining the pertinent type material. The results frequently come as an additional burden to the few specialists of the group, who must go out of their way to deal with avoidable mistakes made in these isolated contributions.

\section{Acknowledgements}

We thank David Notton (NHMUK) for sending to us the photographs of the type specimen of Anthidium multiplicatum. GARM thanks Zoltán Vas for his assistance during visit to the NHMUK and for loan of the study material. This work was supported by the Conselho Nacional de Desenvolvimento Científico e Tecnológico (grants 300501/2016-1 and 309641/2016-0 to GARM).

\section{Conflicts of interest}

The authors declare no conflicts of interest.

\section{Compliance with ethical standards}

Not applicable

\section{Author contribution statement}

GARM planned the work with input from DRP; DRP wrote the first draft of the manuscript. Both authors revised the final version.

\section{References}

Augusto, S. C., Garófalo, C. A., 1998. Behavioral aspects of Hoplostelis bilineolata(Spinola) (Hymenoptera, Megachilidae), a cleptoparasite of Euglossa cordata(Linnaeus) (Hymenoptera, Apidae), and behavior of the host in parasitized nests. Rev. Bras. Entomol. 41, 507-515.

Bennett, F. D., 1966. Notes on the biology of Stelis (Odontostelis) bilineolata (Spinola), a parasite of Euglossa cordata (Linnaeus). J. N.Y. Entomol. Soc. 74, 72-79.

Dominique, J., 1898. Coup d'oeil sur les melliféres sud-américains du Muséum de Nantes. Bull. Soc. Sci. Nat. Ouest Fr. 8, 57-65.

Mahlmann, T., 2020. A new species of the previously monotypic Neotropical cleptoparasitic bee genus Rhynostelis, with notes on Rhynostelis multiplicata (Hymenoptera: megachilidae). J. Melittol. 96, 1-8.

Michener, C. D., 2007. The Bees of the World, 2nd ed. Johns Hopkins University Press, Baltimore.

Michener, C. D., Fraser, A., 1978. A comparative anatomical study of mandibular structure in bees. Univ. Kans. Sci. Bull. 51 (14), 463-482. http://dx.doi.org/10.5962/bhl.part.17245.

Moure, J. S., Urban, D., 1995. [1994] Rhynostelis, gen. n. e notas sobre Hoplostelis Dominique (Hymenoptera, Apoidea, Megachilidae). Rev. Bras. Zool. 11 (2), 297-302. http://dx.doi.org/10.1590/S010181751994000200014.

Parizotto, D., Urban, D., 2012. A revised key to the Neotropical cleptoparasitic anthidiine genera (Hymenoptera, Megachilinae) with notes and description of the male of Rhynostelis Moure \& Urban. ZooKeys 249, 27-35. http://dx.doi.org/10.3897/zookeys.249.4030.

Rasmussen, C., Mahé, G., Hinojosa-Díaz, A., 2007. Taxonomic status of the bees from French Guiana described by Jules Dominique (Hymenoptera: Apidae, Megachilidae, Halictidae). Zootaxa 1423 (1), 59-62. http://dx.doi.org/10.11646/zootaxa.1423.1.5.

Smith, F. (1879). Descriptions of New Species of Hymenoptera in Collection of the British Museum. British Museum, London, 240 pp.

Urban, D., 1967. As espécies do gênero Thygater Holmberg, 1884 (Hymenoptera, Apoidea). Bol. Univ. Fed. Parana Zool. 2 (12), 177-309.

Urban, D., 2003. [2001] Uma nova espécie de Anthidiinae parasita (Hymenoptera, Megachilidae) da Costa Rica. Acta Biol. Parana. 30 (1-4), 1-4.

Urban, D., 2011. Melostelisgen. nov., espécies novas e notas complementares sobre Anthidiini (Hymenoptera, Apidae). Rev. Bras. Entomol. 55, 219-225.

Urban, D., Moure, J. S., 2007. Anthidini Ashmead, 1899, 875-913. In: Moure, J.S., Urban, D., Melo, G.A.R. (Eds.), Catalogue of Bees (Hymenoptera, Apoidea) in the Neotropical Region. Sociedade Brasileira de Entomologia, Curitiba, 1058 pp. 